Fitri Amalia: Pengaruh Pendidikan, Pengangguran Dan Inflasi Terhadap Tingkat Kemiskinan Di Kawasan Timur Indonesia (KTI) Periode 2001-2010

\title{
PENGARUH PENDIDIKAN, PENGANGgURAN DAN INFLASI TERHADAP TINGKAT KEMISKINAN DI KAWASAN TIMUR INDONESIA (KTI) PERIODE 2001-2010
}

\author{
Fitri Amalia*
}

\begin{abstract}
This study aims to determine the effect of education, unemployment and inflation on the level of poverty in Eastern Indonesia (KTI) in the period 20012010. This study uses a sampling techniques to sample the three provinces in Eastern Indonesia, the East Nusa Tenggara, South Sulawesi and Papua. The data used are secondary data is supported by the data panel, the combined time series and cross section data. The analysis shows that the unemployment variable does not affect the level of poverty in Eastern Indonesia. While the other two variables, namely education and inflation have a significant effect with 95\% confidence level of the poverty level. Based on F test statistic, showed all the independent variables (education, unemployment and inflation) simultaneously had no significant effect on the level of poverty in Eastern Indonesia at 95\% confidence level.
\end{abstract}

Keyword: education, unemployment, inflation, level of poverty

\section{PENDAHULUAN}

Didunia,

kemiskinan kerap kali muncul, khususnya di negara-negara yang sedang berkembang maupun negara miskin (Asia, Amerika Latin, Afrika). Hal tersebut didasari oleh minimnya fasilitas, dan sarana guna

\footnotetext{
* Fitri Amalia. Dosen Fakultas Ekonomi dan Bisnis UIN Syarif Hidayatullah Jakarta
}

menunjang kesejahteraan hidup masyarakatnya. Di negara berkembang yang terletak di benua asia seperti Indonesia misalnya, kemiskinan adalah suatu permasalahan yang sering menjadi topik pembahasan dan perbincangan klasik diseluruh kalangan dan tiap lapisan masyarakat. Pada tahun 1976-1996 penduduk Indonesia yang berada 
Fitri Amalia: Pengaruh Pendidikan, Pengangguran Dan Inflasi Terhadap Tingkat Kemiskinan Di Kawasan Timur Indonesia (KTI) Periode 2001-2010

dibawah garis kemsikinan adalah 54,2 juta atau $40,1 \%$, lalu kemudian menurun menjadi 22,5 juta atau $11,3 \%$ dari total penduduk (BPS, 2000).

Namun pada tahun 19971998 krisis moneter yang terjadi telah mengakibatkan meningkatnya jumlah kemiskinan di Indonesia, ketika itu tingkat inflasi mencapai $78 \%$ yang menyebabkan kenaikan ekstrem harga-harga barang secara umum, pada tahun 1996-1998 angka kemiskinan meningkat menjadi $24,29 \%$ atau 49,5 juta jiwa.

Sedangkan International Labour Organization (ILO) memperkirakan jumlah penduduk miskin di Indonesia tahun 1996-1998 mencapai 129,6 juta jiwa atau sekitar 66,3\% (Mubyarto, 2004). Pada tahun setelah terjadinya krisis, tingkat kemiskinan kembali menurun akan tetapi belum kembali seperti saat dimana sebelum terjadinya krisis.

Indonesia memiliki 27 propinsi saat sebelum dilakukannya pemekaran daerah, propinsi-propinsi tersebut kemudian terbagi menjadi dua kawasan yang kita kenal dengan sebutan Kawasan Barat Indonesia (KBI) dan Kawasan Timur Indonesia (KTI). Dalam perjalanannya, ternyata kedua kawasan tersebut memperlihatkan kecenderungan bahwa Propinsipropinsi yang terletak di Kawasan Barat Indonesia (KBI) pada umumnya mengalami perkembangan ekonomi yang lebih cepat di bandingkan daerah atau propinsi yang berada di Kawasan Timur Indonesia (KTI). Sarana transportasi, tingkat fasilitas pendidikan dan kesehatan di KBI masih jauh lebih baik apabila dibandingkan dengan daerah atau propinsi-propinsi yang terletak di Kawasan Timur Indonesia.

Berdasarkan

Indeks Pembangunan Manusia (IPM) KBI pada tahun 2005-2010 selalu lebih tinggi apabila dibandingkan dengan rata-rata IPM KTI yang selalu lebih rendah. Hal tersebut menggambarkan bahwa kualitas manusia yang berada di KBI masih jauh lebih baik daripada kualitas manusia yang berada di KTI. Dilihat dari hal-hal yang disebutkan di atas, Itulah mengapa kemiskinan bisa dikatakan seperti layaknya sebuah lingkaran setan dimana tingkat produktifitas, tingkat pendidikan, kesehatan, kesejahteraan masyarakat yang rendah dimana pendapatan kecil, dan juga tingkat pengangguran di anggap sebagai suatu permasalahan yang saling 
Fitri Amalia: Pengaruh Pendidikan, Pengangguran Dan Inflasi Terhadap Tingkat Kemiskinan Di Kawasan Timur Indonesia (KTI) Periode 2001-2010

berkaitan dan saling mempengaruhi dalam proses terjadinya kemiskinan.

\section{KAJIAN PUSTAKA}

\section{a. Kemiskinan}

Menurut Mubyarto (2004) bahwa: "Kemiskinan di gambarkan sebagai kurangnya pendapatan untuk memenuhi kebutuhan hidup yang pokok atau kebutuhan hidup minimum yaitu sandang, pangan, perumahan, pendidikan dan kesehatan.

Menurut Lincolin Arsyad (2010) ukuran indikator kemiskinan antara lain :

1. Tingkat komsumsi beras perkapita per tahun.

2. Tingkat pendapatan

3. Indikator kesejahteraan rakyat.

Menurut publikasi PBB tahun

1961 yang berjudul internatonal definition and measurement of levels of living: an interim guide dikemukakan ada sembilan komponen kesejahteraan, antara lain: kesehatan, konsumsi makanan dan gizi, pendidikan, kesempatan kerja, perumahan, jaminan sosial, sandang, rekreasi dan kebebasan. UNDP (United Nation Development Program) memperkenalkan indeks kemiskinan manusia. Menurut UNDP adalah bahwa tolak ukur kemiskinan dari seseorang adalah jika dia tidak mampu menjangkau (atau bahkan tidak mempunyai akses) terhadap sarana publik dasar dan tingkat kualitas hidup mereka sendiri rendah, bukan berapa banyak pendapatan per dolar perkapita yang mampu mereka raih setiap harinya. (Lincolyn Arsyad, 2010:305)

Konsep lingkaran kemiskinan menganggap bahwa: ketidakmampuan untuk mengerahkan tabungan yang cukup, kurangnya keahlian masyarakat yang relatif masih rendah, dan kurangnya faktor pendorong untuk kegiatan penanaman modal, adalah merupakan tiga faktor utama yang menghambat proses pembentukan modal dan pembangunan ekonomi di negara sedang berkembang.

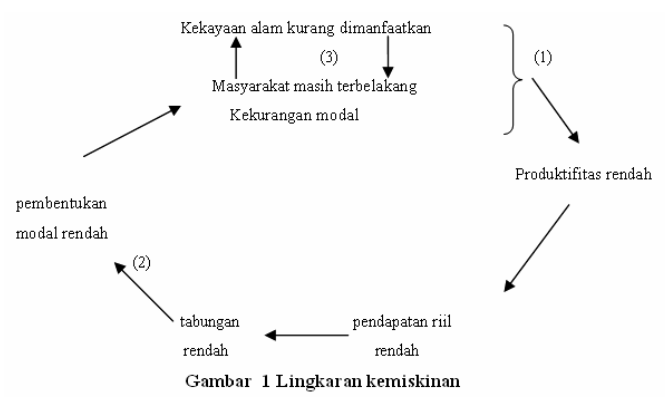

\section{b. Pendidikan}

Dalam UU SISDIKNAS NO. 20 tahun 2003 disebutkan bahwa Pendidikan adalah usaha sadar dan terencana untuk mewujudkan 
Fitri Amalia: Pengaruh Pendidikan, Pengangguran Dan Inflasi Terhadap Tingkat Kemiskinan Di Kawasan Timur Indonesia (KTI) Periode 2001-2010

suasana belajar dan proses pembelajaran agar peserta didik keluarga (Sadono Sukirno, secara aktif mengembangkan potensi dirinya untuk memiliki kekuatan spiritual keagamaan, pengendalian diri, kepribadian, kecerdasan, ahlak mulia, serta keterampilan yang diperlukan dirinya dan masyarakat.

Teori pertumbuhan endogen yang di kemukakan oleh Lucas dan Romer adalah suatu teori yang didalamnya menjelaskan akan pentingnya pendidikan/human capita/ terhadap tingkat pendapatan perkapita maupun pertumbuhan ekonomi suatu wilayah atau negara.

\section{Pengangguran}

Pengangguran adalah suatu keadaan dimana seseorang yang tergolong dalam angkatan kerja ingin mendapatkan pekerjaan tetapi belum dapat memperolehnya. Ditinjau dari sudut individu, pengangguran menimbulkan masalah ekonomi dan sosial kepada siapa yang mengalaminya. ketiadaan pendapatan menyebabkan para penganggur harus mengurangi pengeluaran konsumsinya. Selain itu pengangguran juga dapat mengganggu taraf kesehatan

2004:14).

\section{Teori Pengangguran}

Lewis menyatakan tujuan dari teori mengenai proses pembangunan yang khusus di peruntukan bagi Negara yang menghadapi masalah kelebihan tenaga kerja. Lewis menganggap di banyak Negara berkembang terdapat tenaga kerja yang berlebih, akan tetapi sebaliknya menghadapi masalah kekurangan modal, dan keluasan tanah yang belum digunakan sangat terbatas. (Sadono Sukirno, 2006:196)

\section{Teori Ranis dan Fei}

Teori ini dikembangkan oleh dua ahli ekonomi, yaitu Gustav Ranis dan John Fei. Analisis teori Ranis dan Fei dimaksudkan sebagai teori pembangunan untuk Negara yang menghadapai masalah kelebihan jumlah penduduk sehingga menghadapi masalah pengangguran yang serius, dan kekayaan alam yang tersedia dan dapat dikembangkan sangat terbatas. (Sadono Sukirno, 2006:202) 
Fitri Amalia: Pengaruh Pendidikan, Pengangguran Dan Inflasi Terhadap Tingkat Kemiskinan Di Kawasan Timur Indonesia (KTI) Periode 2001-2010

\section{d. Inflasi}

Inflasi dapat didefinisikan sebagai kenaikan harga-harga yang berlaku dalam suatu perekonomian. Tingkat inflasi berbeda dari satu periode ke periode yang lain. Dan tingkat inflasi berbeda antara Negara yang satu dengan Negara yang lain. Dimana tingkat inflasi itu di bagi tiga, 1) tingkat inflasi rendah yaitu mencapai dibawah 2 atau 3 persen. Tingkat inflasi moderat mencapai di antara 4 sampai 10 persen sedangkan tingkat inflasi yang serius dapat mencapai tingkat beberapa puluh atau beberapa ratus persen dalam setahun (Sadono Sukirno, 2004:14).

\section{Teori Inflasi}

\section{Keynesian model}

Menurut pemikiran Keynes, dia mengatakan bahwa inflasi terjadi karena masyarakat ingin hidup di luar batas kemampuan ekonomisnya, sehingga dari keadaan tersebut kemudian nantinya akan menyebabkan permintaan masyarakat terhadap barang-barang akan melebihi jumlah barang-barang yang tersedia, akibatnya akan terjadi inflationary gap. Keadaan Keterbatasan jumlah persediaan barang ini terjadi karena dalam jangka pendek kapasitas produksi tidak dapat dikembangkan untuk mengimbangi kenaikan permintaan, Dengan kata lain, dalam jangka pendek kapasitas produksi tidak mengalami peningkatan secepat kenaikan permintaan yang terjadi. (Adwin S. Admaja, 1999).

\section{Pandangan golongan strukturalis}

Dengan semakin banyaknya jumlah penduduk dan ditambah lagi dengan meningkatnya sektor industri akibat dari perkembangan ekonomi, akan membuat perpindahan penduduk dari sektor pertanian menuju sektor industri. keadaan tersebut kemudian akan menyebabkan kenaikan permintaan akan bahan makanan namun di satu sisi jumlah produksi akan bahan makanan menurun sehingga akan mengakibatkan harga bahan makanan mengalami kenaikan. dengan meningkatnya harga bahan makanan akan menimbulkan tuntutan untuk menaikan tingkat upah di sektor industri dan selanjutnya akibat dari meningkatnya upah maka akan meningkatkan pula biaya produksi yang nantinya akan mengakibatkan barang-barang industri juga akan 
Fitri Amalia: Pengaruh Pendidikan, Pengangguran Dan Inflasi Terhadap Tingkat Kemiskinan Di Kawasan Timur Indonesia (KTI) Periode 2001-2010

mengalami kenaikan (Sadono

Sukirno, $2006: 320$ ).

\section{METODOLOGI PENELITIAN}

Penelitian ini bersifat kuantitatif dan data yang digunakan adalah data panel, menggunakan data dari 3 Propinsi yang berada di Kawasan Timur Indonesia. Propinsi tersebut antara lain: Nusa Tenggara Timur, Sulawesi Selatan dan Papua. Data yang digunakan yaitu jumlah penduduk miskin $(Y)$, pendidikan $\left(X_{1}\right)$, pengangguran $\left(X_{2}\right)$, inflasi $\left(X_{3}\right)$. Penelitian ini menggunakan data dari tahun 2001-2010.

Data yang di pergunakan dalam penelitian ini adalah data sekunder yang berupa data panel 3 Propinsi (NTT, Sulawesi Selatan, Papua) yang berada di Kawasan Timur Indonesia periode 2001-2010. Data yang digunakan adalah: data jumlah penduduk miskin, jumlah penduduk berdasarkan tingkat pendidikan yang ditamatkan (SMA, SMK, Kuliah), jumlah orang yang menganggur/ sedang mencari pekerjaan dan laju inflasi. Data-data tersebut diperoleh dari Badan Pusat Statistik (BPS).

Dalam penelitian ini sampel yang digunakan adalah 3 Propinsi yang ada di Kawasan Timur Indonesia yaitu NTT, Sulawesi
Selatan dan Papua. Pengambilan tiga propinsi ini dikarenakan jumlah penduduk miskin di propinsi tersebut cukup besar.

Data yang digunakan dalam studi ini merupakan data sekunder berbentuk data panel. Data yang dipergunakan meliputi data jumlah penduduk miskin (JPM), pendidikan (EDU), pengangguran (UN) dan inflasi (INF) yang diperoleh dari Badan Pusat Statistik (BPS).

Metodologi yang digunakan dalam penelitian ini adalah deskriptif kuantitiatif. Sedangkan model dasar yang digunakan dalam penelitian ini adalah sebagai berikut:

JPM $=\mathbf{f}($ EDU, UN, INF)

Keterangan:

JPM = jumlah penduduk miskin di KTI periode 2001-2010

EDU $=$ tingkat pendidikan tertinggi

yang ditamatkan di KTI

periode 2001-2010

UN = jumlah penggangguran di

KTI periode 2001-2010

INF = laju inflasi (dalam persen, $\%$ ) di KTI periode 2001-2010 Metode Estimasi yang digunakan dalam penelitian ini adalah regresi berganda Pooled Least Square (PLS), dengan spesifikasi model sebagai berikut :

$\mathrm{JPM}_{\mathrm{t}}=\beta+\beta 1 \mathrm{EDU}_{\mathrm{t}}+\beta 2 \mathrm{UN}_{\mathrm{t}}+$ $\beta 3$ INF $_{\mathbf{t}}+\mathbf{i}_{\mathbf{t}}$ 
Fitri Amalia: Pengaruh Pendidikan, Pengangguran Dan Inflasi Terhadap Tingkat Kemiskinan Di Kawasan Timur Indonesia (KTI) Periode 2001-2010

\section{HASIL DAN PEMBAHASAN}

Untuk melihat hubungan semua variabel secara simultan maka digunakan F-test. Penerapan $\mathrm{F}$ test ini dijelaskan sebagai berikut:

$\mathrm{H}_{0}: \beta_{1} ; \beta_{2} ; \beta_{3} ;=0$ : Pendidikan, pengangguran dan inflasi secara simultan tidak mempunyai pengaruh terhadap tingkat kemiskinan.
$\mathrm{H}_{1}: \beta_{1} ; \beta_{2} ; \beta_{3} ; \neq 0$ : Pendidikan, pengangguran dan inflasi secara simultan berpengaruh terhadap tingkat kemiskinan.

Berikut adalah tabel hasil regresi yang dapat menunjukkan hasil uji statistik yang meliputi: uji $F$, uji $t$ dan koefisien determinasi.

Tabel 1. Anova

\begin{tabular}{|c|c|c|c|c|c|c|}
\hline \multicolumn{2}{|c|}{ Model } & Sum of Squares & $\mathrm{Df}$ & Mean Square & $\mathrm{F}$ & Sig. \\
\hline \multirow[t]{3}{*}{1} & Regression & $2.523 \mathrm{E} 10$ & 3 & $8.411 \mathrm{Eg}$ & 2.926 & $.122^{\mathrm{a}}$ \\
\hline & Residual & $1.725 \mathrm{E} 10$ & 6 & 2.874E9 & & \\
\hline & Total & $4.248 \mathrm{E} 10$ & 9 & & & \\
\hline
\end{tabular}

a. Predictors: (Constant), Edu, Inf, Un

b. Dependent Variable: Pov

Tabel 2. Coefficient

\begin{tabular}{|c|c|c|c|c|c|c|c|c|c|c|}
\hline \multirow{2}{*}{ Model } & \multicolumn{2}{|c|}{$\begin{array}{l}\text { Unstandardized } \\
\text { Coefficients }\end{array}$} & \multirow{2}{*}{\begin{tabular}{|c}
$\begin{array}{c}\text { Standardiz } \\
\text { ed } \\
\text { Coefficient } \\
\text { s }\end{array}$ \\
Beta
\end{tabular}} & \multirow{2}{*}{$\mathrm{t}$} & \multirow{2}{*}{ Sig. } & \multicolumn{3}{|c|}{ Correlations } & \multicolumn{2}{|c|}{$\begin{array}{l}\text { Collinearity } \\
\text { Statistics }\end{array}$} \\
\hline & B & Std. Error & & & & $\begin{array}{l}\text { Zero- } \\
\text { order }\end{array}$ & $\begin{array}{c}\text { Partia } \\
1\end{array}$ & Part & $\begin{array}{l}\text { Toler } \\
\text { ance }\end{array}$ & VIF \\
\hline $\begin{array}{c}\text { Constan } \\
\text { t) }\end{array}$ & $\begin{array}{c}4172802.52 \\
2\end{array}$ & $\begin{array}{c}1517005.07 \\
8\end{array}$ & & 2.751 & .033 & & & & & \\
\hline Un & .682 & .435 & .547 & 1.567 & .168 & -.064 & .539 & .408 & .556 & $\begin{array}{c}1.79 \\
9\end{array}$ \\
\hline Inf & -16018.235 & 5905.491 & -.854 & 2.712 & .035 & -.420 & -.742 & -.706 & .683 & $\begin{array}{c}1.46 \\
5\end{array}$ \\
\hline Edu & -46483.089 & 18721.424 & -.946 & $\begin{array}{c}- \\
2.483\end{array}$ & .048 & -.286 & -.712 & -.646 & .466 & $\begin{array}{c}2.14 \\
5\end{array}$ \\
\hline
\end{tabular}

a. Dependent Variable: Pov

Berdasarkan hasil anova di atas, maka diketahui bahwa secara simultan pengangguran, inflasi dan pendidikan tidak mempengaruhi jumlah kemiskinan di Kawasan Timur Indonesia yang ditunjukkan 
Fitri Amalia: Pengaruh Pendidikan, Pengangguran Dan Inflasi Terhadap Tingkat Kemiskinan Di Kawasan Timur Indonesia (KTI) Periode 2001-2010

dari tingkat signifikansi $F$ hitung yang lebih besar dari $a=0,05$.

Selanjutnya dilakukan uji signifikansi parameter secara individual/ parsial dengan menggunakan t-test. Berdasarkan uji t pada tabel berikut, terlihat bahwa secara parsial inflasi dan pengangguran mempunyai pengaruh negatif dan signifikan terhadap tingkat kemiskinan pada a $=5 \%$.

Hasil pada tabel 2 di atas menunjukkan bahwa pendidikan memiliki nilai probabilitas sebesar 0.048 , karena probabilitasnya lebih kecil dari tingkat kesalahan sebesar $5 \%$ atau 0,05 maka hasilnya signifikan. Sehingga dapat disimpulkan pendidikan secara parsial berpengaruh signifikan terhadap kemiskinan. Menurut Marliantoro (2004), dalam penelitiannya tentang memahami kemiskinan melalui pembangunan pendidikan dan kesehatan. Pendidikan telah menangani kemiskinan, mau tak mau, tidak dapat lepas dari kualitas sumber daya manusia (dalam konteks ini tingkat pendidikan). Berbagai kajian dan penelitian, telah membuktikan bahwa semakin tinggi pendidikan, semakin tinggi pula tingkat pendapatannya. Ia menjadi sarana ampuh bagi peningkatan sumber daya manusia (Tiptoherijanto, 1983). Dengan kata lain dalam perspektif ekonomi, tingkat pendidikan adalah modal dasar (assets) bagi proses produksi, dan bukan beban proses produksi (liabilities). Seseorang dapat meningkatkan penghasilannya melalui peningkatan pendidikan. Setiap tambahan satu tahun pendidikan, berarti peningkatan kemampuan kerja dan tingkat pendidikan, meskipun juga berarti penundaan penerimaan penghasilan selama satu tahun sekolah tersebut (Simanjuntak, 1982). Dengan demikian pendidikan dipandang merupakan investasi yang imbalannya dapat diperoleh beberapa tahun kemudian dalam bentuk pertambahan hasil kerja, yang pada gilirannya akan mempengaruhi tingkat produktifitas, baik pribadi maupun komunitas atau sektoral.

Inflasi nilai probabilitas sebesar $\quad 0.035, \quad$ karena probabilitasnya lebih besar dari tingkat kesalahan sebesar $5 \%$ atau 0,05 maka hasilnya signifikan. Jika dilihat dari nilai koefisien yang ada, maka inflasi mempengaruhi kemiskinan secara negatif. Hal ini tentunya berbeda dari yang teori sebelumnya dimana inflasi akan 
Fitri Amalia: Pengaruh Pendidikan, Pengangguran Dan Inflasi Terhadap Tingkat Kemiskinan Di Kawasan Timur Indonesia (KTI) Periode 2001-2010

berpengaruh positig bagi tingkat kemiskinan. Namun demikian korelasi negatif antara inflasi dan tingkat kemiskinan diperkuat oleh penelitian Latif Kharie (2007) inflasi merupakan determinan makro ekonomi bagi perubahan kondisi kemiskinan disuatu negara. Suatu pertumbuhan ekonomi yang disertai dengan perbaikan distribusi pendapatan diantara kelompok penerimaan pendapatan dipastikan dapat meningkatkan daya beli kolektif, meningkatkan pengeluaran konsumsi perkapita, sehingga mengurangi jumlah penduduk miskin atau menurunkan tingkat kemiskinan penduduk suatu negara. Demikian juga, suatu peningkatan inflasi dalam batas-batas yang diperlukan, dapat memperbaiki pula kondisi kesejahteraan masyarakat secara umum atau menurunkan tingkat kemiskinan penduduk melalui peningkatan rangsangan produksi pada sektor riil.

Pengangguran memiliki nilai probabilitas sebesar 0.168 , karena probabilitasnya lebih besar dari tingkat kesalahan sebesar $5 \%$ atau 0,05 maka hasilnya tidak signifikan. Sehingga dapat disimpulkan pengangguran secara parsial tidak berpengaruh signifikan terhadap kemiskinan. Menurut Maryono DS
(2001), dari penelitiannya tentang perkembangan pengangguran dan kemiskinan di Indonesia, ada beberapa alasan yang menyebabkan pengangguran terbuka di perkotaan lebih tinggi antara lain adalah bahwa diperkotaan pendidikan masyarakatnya rata-rata lebih tinggi sehingga mereka akan memilih menganggur secara sukarela bila dibanding dengan harus bekerja namun tidak pada bidang pekerjaan atau kompensasi sesuai dengan yang diharapkan. Selain itu juga dapat terjadi karena tingkat pendapatan keluarga yang tinggi sehingga mampu menopang biaya hidup bagi keluarga yang masih menganggur. Dengan demikian mereka hanya akan mencari pekerjaan yang benar-benar sesuai dengan bidang maupun tingkat penghasilan yang diinginkan saja, dan tidak mau mencari pekerjaan yang tidak sesuai dengan bidang dan tingkat upah yang diharapkan.

Untuk mengetahui seberapa besar kemampuan variabel independen menjelaskan variabel dependen. Hasil uji koefisien determinasi menunjukan bahwa nilai koefisien determinasi $\left(R^{2}\right)$ sebesar 0.391 . Hal ini berarti bahwa variabel bebas yang terdiri pengangguran, inflasi dan tingkat pendidikan 
Fitri Amalia: Pengaruh Pendidikan, Pengangguran Dan Inflasi Terhadap Tingkat Kemiskinan Di Kawasan Timur Indonesia (KTI) Periode 2001-2010

mempunyai pengaruh terhadap dipengaruhi oleh variabel lain yang kemiskinan sebesar $\quad 39,1 \%$. tidak dimasukkan kedalam model.

Sedangkan sisanya sebesar 60,9\%

Tabel 3. Model Summary

\begin{tabular}{|c|c|c|c|c|c|c|c|c|c|c|}
\hline \multirow[b]{2}{*}{ Model } & \multirow[b]{2}{*}{$R$} & \multirow[b]{2}{*}{$\begin{array}{c}\mathrm{R} \\
\text { Square }\end{array}$} & \multirow[b]{2}{*}{$\begin{array}{l}\text { Adjusted } \\
\text { R Square }\end{array}$} & \multirow{2}{*}{$\begin{array}{l}\text { Std. Error } \\
\text { of the } \\
\text { Estimate }\end{array}$} & \multicolumn{5}{|c|}{ Change Statistics } & \multirow[b]{2}{*}{$\begin{array}{l}\text { Durbin- } \\
\text { Watson }\end{array}$} \\
\hline & & & & & $\begin{array}{c}\text { R Square } \\
\text { Change }\end{array}$ & $\begin{array}{c}\mathrm{F} \\
\text { Change }\end{array}$ & df1 & df2 & $\begin{array}{c}\text { Sig. F } \\
\text { Change }\end{array}$ & \\
\hline 1 & $.771^{\mathrm{a}}$ & .594 & .391 & 53612.955 & .594 & 2.926 & 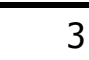 & 0 & .122 & 1.031 \\
\hline
\end{tabular}

PENUTUP

Berdasarkan hasil analisis, menunjukan bahwa variabel pengangguran nyatanya tidak berpengaruh terhadap tingkat kemiskinan di Kawasan Timur Indonesia (NTT, Sulawesi Selatan dan Papua). Tidak berpengaruhnya variabel pengangguran salah satunya dapat terjadi karena tingkat pendapatan keluarga yang tinggi sehingga mampu menopang biaya hidup bagi keluarga yang masih menganggur. Dengan demikian mereka hanya akan mencari pekerjaan yang benar-benar sesuai dengan bidang maupun tingkat penghasilan yang diinginkan saja, dan tidak mau mencari pekerjaan yang tidak sesuai dengan bidang dan tingkat upah yang diharapkan.

Variabel inflasi berpengaruh negatif terhadap tingkat kemiskinan di KTI. Hal ini dapat disebabkan karena inflasi merupakan determinan makro ekonomi bagi perubahan kondisi kemiskinan disuatu negara. Suatu pertumbuhan ekonomi yang disertai dengan perbaikan distribusi pendapatan diantara kelompok penerimaan pendapatan dipastikan dapat meningkatkan daya beli kolektif, meningkatkan pengeluaran konsumsi perkapita, sehingga mengurangi jumlah penduduk miskin atau menurunkan tingkat kemiskinan penduduk suatu negara Dari ketiga variabel pendidikan merupakan salah satu faktor yang berpengaruh secara positif terhadap kemiskinan di KTI. Pendidikan dipandang merupakan investasi yang imbalannya dapat diperoleh beberapa tahun kemudian dalam bentuk pertambahan hasil kerja, yang pada gilirannya akan mempengaruhi tingkat produktifitas, 
Fitri Amalia: Pengaruh Pendidikan, Pengangguran Dan Inflasi Terhadap Tingkat Kemiskinan Di Kawasan Timur Indonesia (KTI) Periode 2001-2010

DAFTAR PUSTAKA

Admaja, S. Adwin. 1999. "Inflasi di Indonesia : Sumber-sumber Penyebab Dan Pengendalianya". Vol 1, No 1: 54-67: Jurnal Akuntansi Dan Keuangan.

Arsyad, Lincolin. 2010. "Ekonomi Pembangunan". UPP STIM YKPN, Yogyakarta.

Gonzalez , Rosario R. dan Martin. 2006. "The Daynamic of Poverty in Germany 19851995: Which Factors Influence The Duration of a Spell of Poverty" $46^{\text {th }}$ Congress of the European Regional Science Association, Volos.

Gujarati,

D. 2006. "Dasar-Dasar Ekonometrika". Edisi III, jilid 1, Erlangga, Jakarta.

2006. "Dasar-Dasar Ekonometrika". Edisi III, jilid 2, Erlangga, Jakarta,

Insukindro, Maryatmo dan Aliman. 2001. "Modul Ekonometrika Dasar dan Penyusunan Indikator Unggulan

Ekonomi". LOKAKARYA, Makasar,

Kharie, Latif. 2007. "Pertumbuhan Ekonomi, Inflasi, dan Kemiskinan di Indonesia :
1976-2005"Vol I/ No. 1/ Mei 2007 , Cita Ekonomika,

Mankiw, Gregory.

2006. "Makroekonomi".

Erlangga, Jakarta,

Marliantoro, AY, Oelin. 2004, "Memahami Kemiskinan

Melalui Pembangunan

Pendidikan dan Kesehatan", Ganesha, LIPI: Jakarta

Maryono, DS. 2001, "Perkembangan Pengangguran Dan Kemiskinan di Indonesia",STIE Stikubank: Semarang.

Mubyarto. 2004"Kemiskinan, Pengangguran, dan Ekonom Indonesia" Vol. III, No 2 : Jurnal Dinamika Masyarakat, Mussawir. 2009. "Analisis Masalah Kemiskinan Nelayan Tradisional di Desa Padang Panjang Kecamatan Susoh Kabupaten Aceh barat daya Propinsi Nanggroe Aceh Darussalam".

Oktapriono, angga. 2008 "Analisis Dampak Investasi

Pemerintah

Sektor

Pendidikan dan Kesehatan Terhadap Pembangunan Manusia (Studi kasus: Kawasan Timur Indonesia Periode 2001-2003)" Institut Pertanian Bogor, Bogor, 
Fitri Amalia: Pengaruh Pendidikan, Pengangguran Dan Inflasi Terhadap Tingkat Kemiskinan Di Kawasan Timur Indonesia (KTI) Periode 2001-2010

P. Michael, Todaro dan Stephen C. Smith. "Pembangunan

Ekonomi di Dunia Ketiga". Erlangga, Jakarta

Prastyo, Adit Agus. 2010. "Analisis Faktor-Faktor Yang Mempengaruhi Tingkat Kemiskinan (Studi Kasus 35 Kabupaten/Kota di Jawa Tengah Tahun 2003-2007)". FE Universitas Diponogoro, Semarang,

Prasetyo, Bambang dan Lina Miftahul J annah. 2005. "Metode Penelitian Kuantitatif: Teori dan Aplikasi". PT RAJAGRIFINDO PERSADA, Jakarta,

Rahadian, Muhammad M. 2010 "Analisis Faktor-faktor Yang Mempengaruhi Kemiskinan di Indonesia Tahun 19812007".

Rahardja, pratama dan Mandala Manurung. 2008. "Teori Ekonomi Makro: suatu pengantar". Lembaga Penerbit Fakultas Ekonomi Universitas Indonesia, Jakarta,

Samuelson dan Nordhaus. 2004. "Ilmu Makro Ekonomi". PT. Media Global Edukasi, Jakarta,
Sukirno, Sadono. 2006. "Ekonomi Pembangunan : Proses, Masalah, dan Dasar Kebijakan". Kencana, Jakarta, 2004. "Makroekonomi Teori Pengantar". Rajagrafindo, Jakarta,

Sulistina, Utami. "Kemiskinan dan Distribusi Pendapatan Rumah Tangga Petani (Studi Kemiskinan di Desa Sumberagung, Kecamatan Mayudan, Kabupaten Sleman, Propinsi Daerah Istimewa Yogyakarta)". Jurnal IImu Sosial Alternatif, Yogyakarta.

Susanti, Evi Tasri. 2006 "Analisis Kemiskinan di Sumatera barat" Vol. 12 No. 2 : Media Ekonomi,

Winarno, Wing Wahyu. 2007. "Analisis Ekonometrika dan Statistika dengan Eviews". UPP STIM YKPN, Yogyakarta. 